\title{
Water Balance and Forest Productivity in Mediterranean Mountain Environments
}

\author{
Giuseppe Scarascia-Mugnozza*1, Giovanni Callegari², Antonella Veltri² \\ and Giorgio Matteucci ${ }^{2}$
}

${ }^{1}$ CRA - Dipartimento Agronomia, Foreste e Territorio

Via del Caravita 7/a, 00186 Roma, Italy

${ }^{2}$ CNR-ISAFOM - Consiglio Nazionale delle Ricerche, Istituto per i Sistemi Agricoli e Forestali del Mediterraneo Via Cavour 4-6, 87036 Rende (CS), Italy

Received: 5 August 2009. Accepted: 11 January 2010.

\begin{abstract}
The availability of water resources is one of the major drivers affecting forest and agricultural productivity. The sensitivity of Mediterranean forest species to water shortage is becoming even more relevant in relation to climate changes, that for Southern Europe could lead to an increase in temperature of 2 to $3{ }^{\circ} \mathrm{C}$, paralleled by a decrease of 5 to $15 \%$ of summer rainfall. It is then important to study the relationship between water balance and productivity of important forest tree species such as beech and mountain pines that represent the upper limit of forest vegetation in almost all the Apennines range. In the present paper, the measurements of water balance, evapotranspiration, carbon exchange and productivity in beech and pine forests of central-southern Italy (Abruzzo and Calabria regions) are reported. The results are obtained in the course of several years of experimentation with innovative techniques and integrated at the canopy level.
\end{abstract}

Key-words: forest hydrology, net ecosystem exchange, global change, Mediterranean mountain forests, forest evapotranspiration.

\section{Introduction}

The availability of water resources is crucial, not only for the distribution of vegetation on the land surface, but also because it is one of the major drivers affecting forest and agricultural productivity. In fact, water availability influences the plant water status and, in cases of high water deficits, can determine the reduction or shutdown of photosynthesis and growth and the alteration of metabolic processes, up to plant death. In the Mediterranean area, rainfall is mostly concentrated in winter, while summer is characterized by long periods of drought, during which high temperatures and low air humidity result in higher evaporative demands, causing the water deficiency to be particularly harmful. The sensitivity of Mediterranean forest tree species to drought becomes relevant especially considering the ongoing climatic and en- vironmental changes (global change).

The increase of carbon dioxide concentration in the atmosphere, largely due to the use of fossil fuels and to tropical deforestation, and the ensuing climate change, are expected to cause the potential increase of $+2{ }^{\circ} \mathrm{C}$ average winter temperature and $+2-3{ }^{\circ} \mathrm{C}$ in summer, accompanied by a slight increase in winter and a decrease of $5-15 \%$ of summer precipitations, resulting in a decrease of $15-25 \%$ of soil water content during summer (IPCC, 2007). Furthermore, careful analyses carried out on the Italian long term weather data collected over more than 200 years have already shown substantial and significant variations in temperature and precipitation on the peninsula (Brunetti et al., 2006). In this regard, many changes are already occurring globally as described in the latest report of Intergovernmental Panel on Climate

\footnotetext{
* Corresponding Author: Tel.: +39 06 69531258; Fax: +39 06 69531270; E-mail address: giuseppe.scarascia@entecra.it
} 
Change (winner of 2007 Nobel Peace Prize together with $\mathrm{Al}$ Gore). In particular (IPCC, 2007):

- in the ranking of the hottest years since the starting of instrumental data (1850), eleven of the 12 years between 1995 and 2006 are positioned in the first 12 places, the increase of temperature in the period 1906-2005 being $0.74{ }^{\circ} \mathrm{C}$ and the growth rate of the last 50 years $\left(0.13{ }^{\circ} \mathrm{C} \mathrm{y}^{-1}\right)$ being about twice that of the last 100 years, indicating an accelerating trend. Moreover, during the same period, cold days and nights have become less frequent, while hot days and heat waves (as in 2003, 2005 and 2007 in Europe) are becoming more frequent;

- the rate of temperature increase at high latitudes (Arctic, boreal areas) is about twice than the global one. The area with seasonal permafrost decreased by $7 \%$ in the Northern Hemisphere;

- clear trends were detected for precipitations in the 1990 to 2005 time interval, with Sahel, the Mediterranean, South Africa and parts of Southern Asia showing significant decreases in rainfall, while an increase is reported in the southern part of the American continent, northern Europe and northern and central Asia. Moreover, the intensity of single rainfall events has been increasing in almost all regions;

- since the '70s, drought periods have been longer and more intense in tropical and subtropical areas;

- direct observations of ocean sea temperatures, starting from 1961, indicate that the average temperature of the oceans has increased down to a depth of $3000 \mathrm{~m}$. The ocean, absorbing heat (about $80 \%$ of that added to the climatic system), tends to expand, contributing to the general trend of increase in sea level;

- glaciers, snow cover and ice caps in Greenland and Antarctica have decreased. Also this process contributes to the rise of sea level that, globally, showed an increasing rate of $1.8 \mathrm{~mm}$ per year between 1961 and 2003, growing to $3.1 \mathrm{~mm}$ per year between 1993 and 2003.

Presently, all these evidences suggest that global warming is unequivocal and that the responsibility could be assigned with very high confidence to human activity (IPCC, 2007); all this implies an inevitable and worrying impact on the hydrological balance of ecosystems and large watersheds, especially in the most vulnerable areas of the Earth.

It is crucial to understand how forest ecosystems respond to environmental factors and to climate change, particularly at the border of species natural ranges, such as at the upper limit of tree vegetation. In fact, in those areas, climate change could have a more significant impact than in other conditions. The range of European beech (Fagus sylvatica L.) and black pines (Pinus laricio Poir.) cover much of the intermediate alpine elevations and of the upper Apennine mountain region (Hofmann, 1991). In almost all the Apennine range, beech and black pine represent the upper limit of forest vegetation. It is therefore crucial to study the relationship between water balance and forest productivity in ecosystems of the Fagetum phytoclimatic belt, in central and southern Italy.

\section{Materials and methods}

The results presented in this work derived from long-term research sites, installed between 1990 and 2003, in a mature beech forest of Abruzzo (Collelongo, L'Aquila, $1560 \mathrm{~m}$ a.s.l., measurements started in 1991-93) and in a planted black pine forest (Bonis experimental watershed, Sila Greca, $1171 \mathrm{~m}$ a.s.l., installed in 2003) in Calabria, by National Research Council (CNR) and the University of Tuscia.

These sites have been equipped with micrometeorological instrumentations to determine the exchange of carbon and water vapour at canopy level (eddy covariance technique). Also, the different components of forest productivity and water balance and the allocation of absorbed carbon to different plant and ecosystem compartments have been regularly measured. Details about the experimental design can be found in several papers published over the years (Valentini et al., 1996; Matteucci, 1999; Scarascia-Mugnozza, 1999; Scarascia-Mugnozza et al., 2003; Scartazza et al., 2004; Marino et al., 2005; Matteucci and Scarascia Mugnozza, 2007).

The forest water balance can be summarized by the following equation:

$$
P-(I t+R+D \pm D s+E v s+T)=0
$$


where $P$ is precipitation, $I t$ is the precipitation intercepted and evaporated, $R$ indicates the runoff on the ground; $D$ represents the horizontal subsurface runoff and infiltration, $D s$ is the change in soil water content; Evs indicates soil evaporation; $T$ the plant transpiration. This equation takes into account the pathways taken by water to enter the ecosystem, to move within the ecosystem and leaving it (Fattorelli, 1987). The sites are equipped with rain gauges to measure precipitation above the crown $(P$ in Eq. 1), and with measuring devices for the components of throughfall $(T F)$ and stemflow $(S F)$. The sum of these two precipitation components equals to the available water supply to the soil, while the difference between total rainfall and the former components corresponds to the interception (It in Eq. 1).

In the study site of Collelongo, $R$ and $D$, are not continuously measured but, in most occasions, can be considered negligible. At the Bonis watershed, measurements of $R$ have been performed on experimental basis on thinned/unthinned plots (Veltri et al., 2001; Callegari et al., 2003) and on plots exposed to different level of forest fire (Bovio et al., 2001). In the beech forest, soil water content has been measured with the TDR technique every 15-30 days from 1996 to 2004 and continuously (30 minutes average) from end of 2004 up to now. At the flux tower of Bonis, soil water content is measured continuously since 2004 while it has been previously measured during experiments on the effect of management on water balance. At both sites, canopy fluxes are measured using the eddy covariance technique (Aubinet et al., 2000), providing values representative of some hectares of forest. These measurements when added up on annual basis, lead to the assessment of net absorption (or release) of carbon and total evapotranspiration (ET) from forest ecosystems. Evapotranspiration, being the sum of Evs and $T$ in Eq. 1, allows to close the simplified water balance equation:

$$
T F+S F=E T \pm D s
$$

Although located in mountain environments, the beech and black pine forests are subject to considerable climate variability on an yearly bases with summer water deficits being not exceptional (Scarascia-Mugnozza et al., 2003).

\section{Ecosystem productivity as affected by Sclimatic variability}

Forests occupy about $30 \%$ of the land surface, but their total carbon stock represents $80 \%$ of the total aboveground carbon and $40 \%$ of the underground carbon of all terrestrial ecosystems; also, forests are responsible for 60 to $70 \%$ of total land primary productivity (Melillo et al., 2003). As for the carbon inflow and outflow, it should be underlined that $70 \%$ of carbon exchanges between the biosphere and the atmosphere takes place at the level of forest ecosystems. This confirms the important role of forests in the global biogeochemical C-cycle even in the context of growing carbon emissions into the atmosphere and progressing climate change. Unfortunately, Mediterranean ecosystems are among those most susceptible to global warming (Schröter et al., 2005) while negative effects on productivity at the southern limit of the range of beech have already been reported (Jump et al., 2006).

Long-term continuous measurements of carbon exchange at ecosystem scale by eddy covariance technique (net carbon exchange at ecosystem scale or Net Ecosystem Exchange, NEE) are capable of detecting changes in the carbon cycle due to extreme events, namely very hot and dry years. Events such as those that occurred in summer 2003 or 2007 are able to greatly limit the net carbon absorption of forest ecosystems located in Mediterranean mountains, as observed in the pine forest of Sila Greca (Fig. 1) in 2007 when during August, cumulative values of NEE were 20 to $30 \%$ lower compared to 2003, 2004 and 2005. Similar findings were detected in the beech forest of Collelongo in the year 1993 (Valentini et al., 1996), 2000 (Scarascia-Mugnozza et al., 2003) and 2007.

Therefore it is becoming clear that even shade-tolerant, hardwood forests such as Mediterranean-mountain beech forests, can be greatly impacted by summer drought stress that can significantly reduce primary productivity and carbon absorption.

In summer, soil water content in the Collelongo beech forest is affected by irregular precipitation and intense ecosystem evapotranspiration and, when drought is particularly strong, soil moisture values may be below $15 \%$ in the first $20 \mathrm{~cm}$ of soil and less than $20 \%$ in whole 


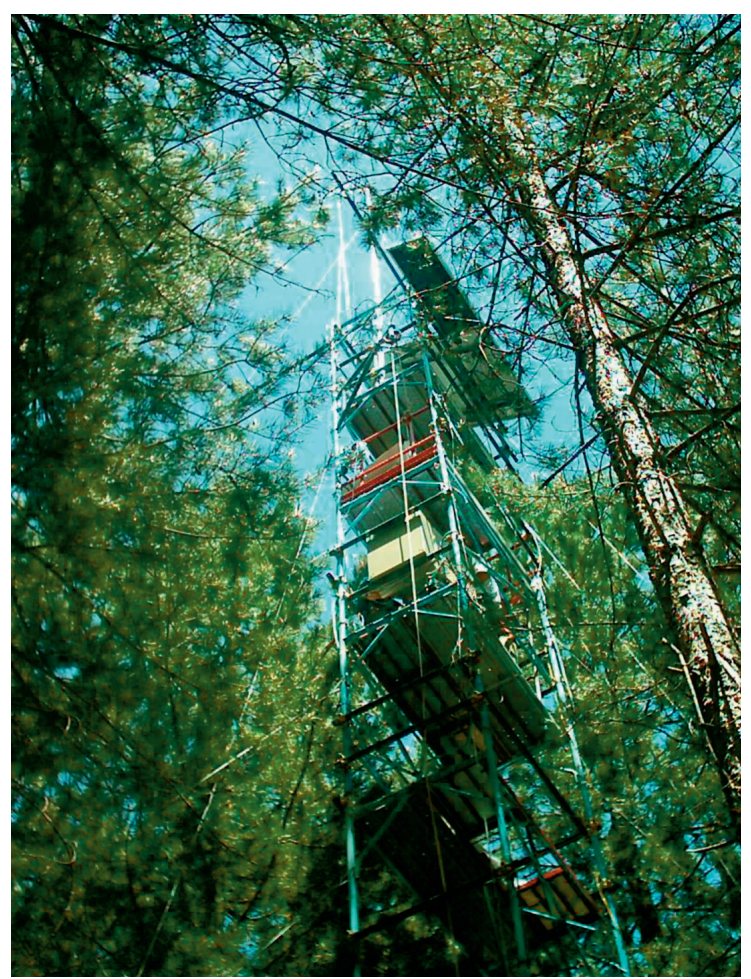

Figure 1. System for measuring carbon fluxes and evapotranspiration in forest of black pines in the Parco Nazionale della Sila (Calabria).

profile $(0-90 \mathrm{~cm})$. These conditions have occurred repeatedly in recent years, when evapotranspiration varied between 2 and $4 \mathrm{~mm}$ per day along the growing-season, with overall evapotranspiration losses of 200 to $400 \mathrm{~mm}$. Precipitation during the growing season in Collelongo was generally sufficient to offset the water losses caused by ET but even in this case, the rainfall distribution should be carefully considered. In fact, one third of the seasonal rainfall, up to $150 \mathrm{~mm}$, can be concentrated between midSeptember and mid October, during the late growing season, when ecosystem functionality start to decrease, while a significant proportion (up to a quarter) may fall in the month of May, when the forest is leafing out and Leaf Area Index is growing from zero to full coverage.

More than $60-70 \%$ of annual rainfall (averaging $1200 \mathrm{~mm}$ annually) is falling down during the dormant period, recharging the soil and preparing the vegetation recovery, but not all this water is available to be fully utilized by the vegetation, also for the fragmented and carsic geologic feature of the site. The imbalance be- tween water supply and consumption, typical of the summer conditions, may run up until mid September. Therefore, during summer, the ecosystem must rely on ground water reserves or on herratic thunderstorms to respond to atmospheric evapotranspiration demands.

To test whether the total water resources have been sufficient to sustain the water consumption of the forest site, the site water balance was assessed in some representative years. The following parameters were considered in the computation: the quantity of water lost from the different soil layers measured with the TDR, the contribution of precipitation output (the sum of SF and TF) and the evapotranspiration (ET). The water balance, the difference between precipitation output (PU, net interception) and the evapotranspiration should be equal to the change in water content of soil in the soil layers explored by the roots.

Between May and September this difference was, on average, equal to $-130 \mathrm{~mm}$, a figure which makes up $75 \%$ of the variation of soil water content between 0 and $70 \mathrm{~cm}(175 \mathrm{~mm})$, being the depth interval where most of the absorbing roots are located (Dore, 1995). During the time needed for leaf area index to reach the maximum value (in late June-early July) PU-ET $(-60 \mathrm{~mm})$ represented almost $80 \%$ of the variation in the first $70 \mathrm{~cm}(75 \mathrm{~mm})$ (Scarascia Mugnozza et al., 2003).

In years when the evapotranspiration reached very high values, or when soil water storage was insufficient to supply the evapotranspiration demand, water stress conditions that could limit the carbon absorption may develop even in the mountains of the Mediterranean region.

In fact, there is a relationship between plant water potential and maximum instantaneous canopy-level carbon exchange (Fig. 2). From ecophysiological studies, it is well known the relationship between water potential and gas exchange at the individual leaf. The measurements conducted at our experimental forest sites have shown that this type of response is present also at the ecosystem scale (Fig. 2).

The water status also affect the growth of tree diameter and biomass production, as measured by dendrometers applied to a representative set of beech trees in the forest, which showed periods of lagging growth during water 


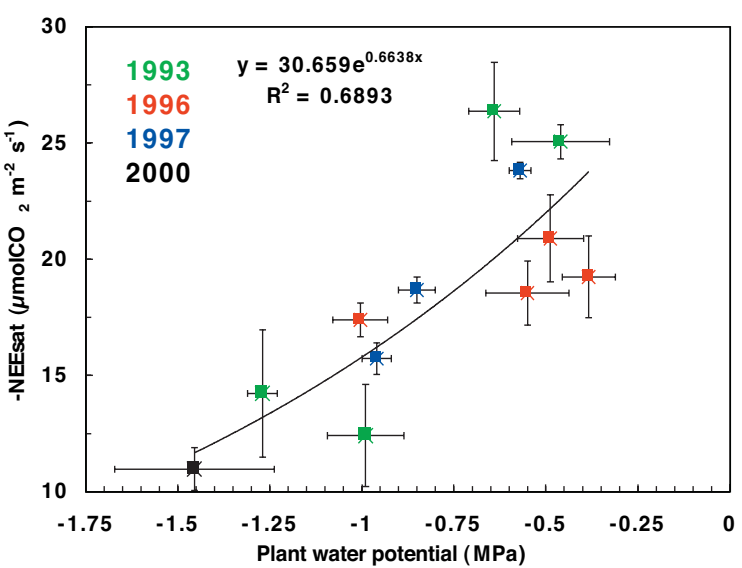

Figure 2. Relationship between water potential measured on the basis of 3-5 trees around the tower to measure the flows and net ecosystem exchange (NEE) at saturation (changed sign).

stress, and sometimes a recovery following the late summer rainfall. Overall, water availability was a major causal factor of forest functioning and of carbon gas exchanges in the study beech forest.

The presented results can be considered significant as they were obtained by measuring the components of the hydrological balance at different integration times, opening new opportunities for the study of water balance in ecosystems. The evapotranspiration responds to climatic factors and is well correlated to the water status of soil and plants. In the presence of climate anomalies, which are expected to increase in the coming years, expecially in the Mediterranean basin, water stress will affect not only the carbon metabolism and the water relations of forest trees but it will also impact on the ecosystem stability and on pest resistance. In fact, in the year 2007 the values of crown transparency, an index of anticipated foliage senescence, in Central Italy exceeded for the first time the critical threshold of $25 \%$ (from CONECOFOR level 1 plots; Petriccione B., personal communication).

The impact of heat waves may occur also at subcontinental scale, resulting in reduced gross primary productivity up to $30 \%$ with effects also on the atmospheric concentration of $\mathrm{CO}_{2}$, as occurred in the year 2003 (Ciais et al., 2005). Moreover, the uncertainty related to the response of terrestrial ecosystems at our latitudes is emphasized by the possibility of catastrophic events such as forest fires that may increase in future, both in number and in destructive potential.

What happened in our country in the summer of 2007 may be a clue of what may happen in the future. In fact, although almost all of the fires are of anthropogenic origins, the enormous increase of forest surface devastated by fires is related to drought conditions that have facilitated both the power and the extensions of wild fires. It should be stressed that similar dynamics have also been reported in northern regions, as Siberia, where, in drought years, the number and extent of fires were higher than in wetter years, including almost virgin forests (Mollicone et al., 2006).

\section{Acknowledgments}

Lecture key-note presented during the AQUATER project final conference held in Bari (Italy) on 12-13 May 2009. The support of the CONECOFOR and EU-FUTMON projects is gratefully acknowledged as well as the collaboration with the CNR-ISAFOM and CNR-ISE institutes.

\section{References}

Aubinet M., Grelle A., Ibrom A., Rannik Ü., Moncrieff J., Foken T., Kowalski A.S., Martin P.H., Berbigier P., Bernhofer Ch., Clement R., Elbers J., Granier A., Grünwald T., Morgenstern K., Pilegaard K., Rebmann C., Snijders W., Valentini R. \& Vesala T. 2000. Estimates of the annual net carbon and water exchange of forests: the EUROFLUX methodology. Advances in Ecological Research, 30:113-175.

Bovio G., Callegari G., Camia A., Francesetti A., Iovino F., Porto P., Veltri A. 2001. Prove sperimentali per valutare l'impatto degli incendi boschivi sull'idrologia superficiale e sull'erosione dei suoli. L'Italia Forestale e Montana, 4:233-256.

Brunetti M., Maugeri M., Monti F. and Nanni T. 2006. Temperatures and precipitation variabilità in Italy in the last two centuries from homogenised instrumental time series. Int. J. Climatol., 26:345-381.

Callegari G., Ferrari E., Garfî G., Iovino F., Veltri A. 2003. Impact of thinning on the water balance of a catchment in Mediterranean environment. The Forestry Chronicle 79, 2:301-306.

Ciais P., Reichstein M., Viovy N., Granier A., Ogée J., Allard V., Aubinet M., Buchmann N., Bernhofer C., Carrara A., Chevallier F., Noblet N.D., Friend A.D., Friedlingstein P., Grünwald T., Heinesch B., Keronen P., Knohl A., Krinner G., Loustau D., Manca G., Matteucci G., Miglietta F., Ourcival J.M., Papale D., Pile- 
gaard K., Rambal S., Seufert G., Soussana J.F., Sanz M.J., Schulze E.D., Vesala T., Valentini R. 2005. Europe-wide reduction in primary productivity caused by the heat and drought in 2003. Nature, 437:529-533.

Dore S. 1995. Bilancio del carbonio di una faggeta dell'Appennino Centro-Meridionale. Tesi di Laurea, Università degli Studi della Tuscia, Viterbo.

Fattorelli F. 1982. Bilancio idrologico nei bacini forestali. Atti convegno naz. AIGR su: Dinamica dell'acqua nel terreno e bilancio idrologico nei bacini agroforestali, Padova, Italia.

Hofmann A. 1991. Il faggio e le faggete in Italia. Collana Verde, 81, Ministero Agricoltura e Foreste.

IPCC 2007. Summary for Policymakers. In: Solomon S., Qin D., Manning M., Chen Z., Marquis M., Averyt K.B., Tignor M. and Miller H.L. (eds.): Climate Change 2007: The Physical Science Basis. Contribution of Working Group I to the Fourth Assessment Report of the Intergovernmental Panel on Climate Change. Cambridge University Press, Cambridge, United Kingdom and New York, NY, USA.

Jump A.S., Hunt J.M., Peñuelas J. 2006. Rapid climate change-related growth decline at the southern range edge of Fagus sylvatica. Global Change Biology, 12:2163-2174.

Marino C., Manca G., Matteucci G., Scarascia Mugnozza G. (2005). Cambiamenti climatici nel mediterraneo: un caso di studio sul ciclo del carbonio in una pineta della Sila, Calabria. Forest@ 2, 1:52-65. [online] URL: http://www.sisef.it/.

Matteucci G., Scarascia Mugnozza G. 2007. Ecosistemi forestali e mitigazione dei cambiamenti ambientali: sequestro di carbonio in foreste italiane. In: Carli B., Cavarretta G., Colacino M., Fuzzi S. (eds.): Clima e cambiamenti climatici: le attività di ricerca del CNR, ISBN 978-88-8080-075-0, 709-712.
Matteucci G., De Angelis P., Dore S., Masci A., Valentini R. \& Scarascia Mugnozza G. 1999. Il bilancio del carbonio delle faggete: dall'albero all'ecosistema. In: Scarascia Mugnozza G. (ed.): Ecologia strutturale e funzionale di faggete italiane, Edagricole, Bologna, Italia, 133-183.

Melillo J.M., McGuire A.D., Kicklighter D.W., Moore B., Vorosmarty C.J., Schloss A.L. 1993. Global climate change and terrestrial net primary production. Nature, 363:234-240.

Mollicone D., Eva H.D., Achard F. 2006. Human role in Russian wildfires. Nature, 440:436-437.

Scarascia Mugnozza G. 1999. Ecologia strutturale e funzionale di faggete italiane. Edagricole, Bologna, Italia.

Scarascia Mugnozza G., Timarco A., Matteucci G. 2003. Ecosistemi forestali e cambiamenti ambientali: lo studio del bilancio idrologico e della produttività con tecniche innovative ed integrate. In: Atti Convegno Nazionale "Conservazione dell'ambiente e rischio idrogeologico", Assisi (Pg), 11-12 Dicembre 2002, CNR-IRPI-GNDCI, pubbl. 2830, Perugia, Italia, 596604.

Scartazza A., Mata C., Matteucci G., Yakir D., Moscatello S., Brugnoli E. 2004. Comparisons of $813 \mathrm{C}$ of photosynthetic products and ecosystem respiratory $\mathrm{CO} 2$ and their responses to seasonal climate variability. Oecologia, 140:340-351.

Schröter D., Cramer W., Leemans R. 2005. Ecosystem service supply and vulnerability to global change in Europe. Science, 310:1333-1337.

Valentini R., De Angelis P., Matteucci G., Monaco R., Dore S. \& Scarascia Mugnozza G.E. 1996. Seasonal net carbon dioxide exchange of a Beech forest with the atmosphere. Global Change Biology, 2:199-207.

Veltri A., Iovino F., Callegari G. 2001. Impatto della gestione dei rimboschimenti di pino laricio sul bilancio idrico. L'Italia Forestale e Montana, 5:352-361. 